\title{
Induction of $\mathrm{NF}-x \mathrm{~B}$ during monocyte differentiation is associated with activation of HIV-gene expression
}

\author{
G.E. Griffin (1), K. Leung (2), T.M. Folks ${ }^{(3)}$, \\ S. Kunkel (4) and G.J. Nabel (2) \\ (1) Division of Communicable Diseases, St. George's Hospital Medical School, \\ Tooting, London, SW17 ORE, \\ (2) Howard Hughes Medical Institute, University of Michigan Medical Centre, \\ Ann Arbor, MI 48109 (USA), \\ (3) Retrovirus Diseases Branch, CDC, Atlanta, GA 30333 (USA), and \\ (4) Department of Pathology, University of Michigan Medical School, \\ Ann Arbor, MI 48109 (USA)
}

\begin{abstract}
SUMMARY
Cells of the monocyte-macrophage lineage are important targets of HIV infection. We report here that the phenotypic differentiation of monocyte cell lines induced by phorbol esters or tumour necrosis factor $\alpha$ (TNF $\alpha$ ) is associated with expression of nuclear factor kappa B (NF-xB). In parallel with such differentiation, HIV transcription, monitored using an HIV long terminal repeat reportor gene construct, is activated in such cells under the influence of enhanced NF-xB expression. Also, in a promonucyte cell the ahthon:-

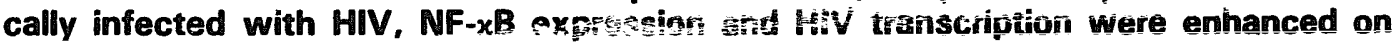
stimulation with phorbol ester or TNF $\alpha$. Thus, stimulation of monocyte cell lines by phorbol esters or TNF $\alpha$ induces cell differentiation and activates HIV transcription. Such a process may have fundamental implications in AIDS pathogenesis in vivo and may be important in disease progression induced by opportunistic infections directly or indirectly involving macrophages.
\end{abstract}

Key-words: HIV, Monocyte, Macrophage, AIDS, NF-xB; Phorbol ester, TNF $\alpha$, Cell maturation, Transcription.

\section{INTRODUCTION}

Monocytes provide an important cellular reservoir for HIV (Ho et al., 1986; Nabel and Baltimore, 1987; Meltzer et al., 1990). The mobility of monocyte macrophages throughout the body into both organs of the reticuloendothelial system, e.g. lymph nodes and spleen and virtually all other organ systems, may provide an important vector for the virus thus facilitating its widespread dis- semination. Macrophages are derived from stem cells in the bone marrow under appropriate stimuli, such as cytokines e.g. granulocyte-macrophage/colonystimulating factor (GM-CSF) and it is thought that such marrow stem cells may be chronically infected per se (Donahue et al., 1987; Folks et al., 1988). In addition, monocytes and macrophages may become infected directly by CD4-receptor-mediated mechanisms. Terminal differentiation into the macrophage phenotype may be induced artificially in vitro using phorbol esters or by more physiological stimuli such as tumour necrosis factor (TNF $\alpha$ ). We report, in this paper, a series of experiments in which we investigated the role of nuclear transcription factor $N F-x B$ in this differentiation process. In addition, we examined the role of this factor in the activation of HIV transcription in such cells induced to differentiate (Griffin et al., 1989). 


\section{MATERIALS AND METHODS}

Cell lines and cells were maintained in RPMI medium enriched with $7.5 \%$ foetal calf serum, glutamine and supplemented with penicillin and streptomycin. Cell lines of promonocytic phenotype HL60 and U937 (non-adherent, absent Mol expression, nonphagocytic, non-specific-esterasenegative) were of human origin. Cells of mature macrophage were of phenotype THP-1, PU5-1.8 and P388D1. Some experiments were carried out on promonocytic cell iine U1, chronically infected with HIV, which expresses very low levels of HIV transcription when unstimulated. In some experiments, monocytes were prepared from human blood of normal volunteers by dextran sedimentation and centrifugation through a discontinuous Ficoll-Hypaque gradient. Monocytes of intermediate homogeneity $(80 \%)$ were prepared by one cycle of adherence onto plastic and further purification $(95 \%)$ was achieved by repeated cycles of washing using RPMl micuins ovè a 3-kiy periud to remove contaminating nonadherent cells. In another series of experimentist, mouse peritoneal macrophages were prepared from ascitic fluid induced by intraperitoneal injection of mineral oil or complete Freund's adjuvant and purified by adherence on plastic and repeated cycles of washing.

\section{Cell transfection}

Cells were transfected either in suspension or adherent using the conventional DEAE-dextran technique (Nabel and Baltimore, 1987) with the exception that $10 \mu \mathrm{M}$ chloroquine was used instead of the higher concentrations of this agent originally described. Cells $\left(10^{7}\right)$ were transfected with $10 \mu \mathrm{g}$ of a plasmid containing the HIV enhancer linked to the chloramphenicol acetyl transferase (CAT) gene. Control experiments were carried out in which cells were transfected with a mutant plasmid $(10 \mu \mathrm{g})$ altered in both $\times \mathrm{B}$-binding sites using DEAE-dextran. Then, $24 \mathrm{~h}$ after transfection, cells were washed with RPMI and incubated with medium alone, or in the presence of $40 \mathrm{nM} 12-0$-tetradecanoyl-phorbol-13-acetate (TPA) or the water-soluble phorbol-12, 13-dibutyrate (PDB) at a concentration of $20 \mathrm{nM}$ which is more easily removed from cells by cycles of washing. Twenty hours after stimulation, cells were harvested and cytoplasmic (Nabel and Baltimore, 1987) and nuclear extracts prepared (Osborn et al., 1989). Protein concentration in the extracts was measured using the Bradford method (Biorad).

\section{Chemical assays}

CAT was assayed by standard methnds (Nophel and Baltinure; 1987) on cytoplasmic extracts. NF. $x \mathrm{~B}$-binding activity was determined on nuclear extracts containing $10 \mu \mathrm{g}$ protein using conventional electrophoretic mobility shift assay (Leung and Nabel, 1988) in the presence of $1 \mu \mathrm{g}$ dIdC. Extracts were incubated with a $x \mathrm{~B}$ probe alone or in the presence of a double-stranded oligonucleotide competitor containing the $x \mathrm{~B}$ site or an unrelated interleukin-2 (IL-2) promoter fragment in order to determine the specificity of binding.

\section{RESULTS}

\section{Nuclear NF-xB-binding activity}

$\mathrm{NF}-x \mathrm{~B}-$ binding activity in nuclear extracts from the cells is shown in figure 1 . No NF- $x$ Bbinding activity was detected in the promonocytic cell lines in the unstimulated state (fig. 1A; HL-60 and U937). However, in these cells, stimulation with TPA resulted in phenotypic differentiation and the appearance of NF-xBbinding activity. In contrast, constitutive NF-xB-binding activity was denionstrated in the mature cell lines (fig. 1A; THP-1, PU5-1.8 and P388DI). In addition, NF-xB-binding activity was detected in the unstimulated state. Since the immature cell lines were both of humar origin and the mature cell lines were derived from mouse cells, we therefore wished to demonstrate NF-xB-binding activity in cells harvested direcly in vivo. NF-xB-binding activity was detected in human monocytes (fig. 1B) and in mouse peritoneal macrophages. TPA stimulation of cells is known to be irreversible but TPA is lipid soluble and cannot be removed from cells. We therefore used PDB, a water-soluble phorbol ester which can easily be removed from coils by washing. in an effort to see if short torm stimilation ( $2 \mathrm{~h}$ ) followed by washing resulted in long-term expression of NF- $x$ B-binding activity. PDB treatment of HL-60 and U937 cells resulted in expression of NF- $x \mathrm{~B}$ after $2 \mathrm{~h}$ of treatment which was still present $48 \mathrm{~h}$ after the phorbol ester was washed away from cells.

\section{HIV transcription}

\section{HIV CAT}

Transcription of transfected HIV-CAT did not occur in immature monocytes, however on stimulation with phorbol ester, transcription was enhanced 17 -fold (fig. 2A). In contrast, the mature cell lines constitutively expressed

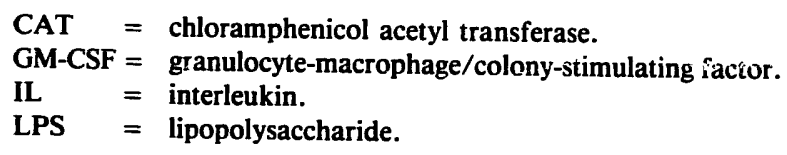

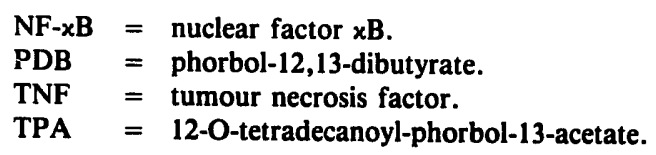


CAT and such expression was not enhanced by phorbol ester stimulation. No CAT activity was detected in any of the cells transfected with the plasmid containing mutant $x B$.

\section{HIV production}

To determine whether monocyte differentiation and NF- $x B$ induction affected production of intact virus, the latently infected U1-cell line (Folks, 1988) was incubated with PDE or TNF $\alpha$. Under these conditions, phenotypic differentiation of the cells occurred as monitored using change in cell surface characteristics (adhesion, Mol expression). In addition, HIV production was enhanced in these cells as shown by increased reverse transcriptase activity and p'24 detected in the incubating medium (fig. 3). Both NF-xB activity and HIV production persisted 24-48 h after the stimulus was removed.

\section{DISCUSSESN}

In these experiments, we have demonstrated that NF- $x$ B-binding activity was induced in nuclear extracts of immature cells of monocyte lineage, in response to stimulation by phorbol ester or cytokine. Such cells assumed and retained a macrophage phenotype as a result of such stimulation. Transient exposure to PDB ( $<2 \mathrm{~h}$ ) did not lead to constitute expression of NF- $x \mathrm{~B}$ binding and had no effect on cell morphology (data not shown). Once monocyte differentiation occurred, however, NF- $\times$ B-binding activity remained, as seen constitutively expressed in normal monocytes prepared from human blood and mouse peritoneal exudate (fig. 1).

In the process of cell differentiation, we have demonstrated that the appearance of NF- $x \mathrm{~B}$ contributes to the activation of HIV in monocytes. This has great clinical implications in that the presence of an opportunistic infection, or HIV infection of monocyte/macrophages per se, is likely to activate HIV transcription and therefore presumably enhance disease progression. It is known, however, that NF- $x \mathrm{~B}$ is not the sole activator of HIV in macrophages. For example GM-CSF, which does not induce NF- $x \mathrm{~B}$ binding, activates HIV expression in mature macrophages (Koyanagi et al., 1988) which already contain NF- $x B$, and therefore alternate non-NF- $x \mathrm{~B}$ activation mechanisms are likely to exist in vivo.

Phorbol esters provide a potent reproducible stimulus in vitro for monocyte differentiation and HIV activation; however, such a stimulus is artificial. It is now becoming apparent that, in clinical HIV infection, the physiological stimuli most likely to induce HIV activation are the cytokines or some bacterial products, for example endotoxin (LPS). HIV infection of monocyte/macrophages is clearly an important cell-activating event per se and several groups have reported stimulation of cytokine transcription and release in response to this event.

For example, the production of $\mathrm{TNF} \alpha, \beta$ and interferon has been demonstrated in inonocytes (Vyakarnam et al., 1990). In addi-

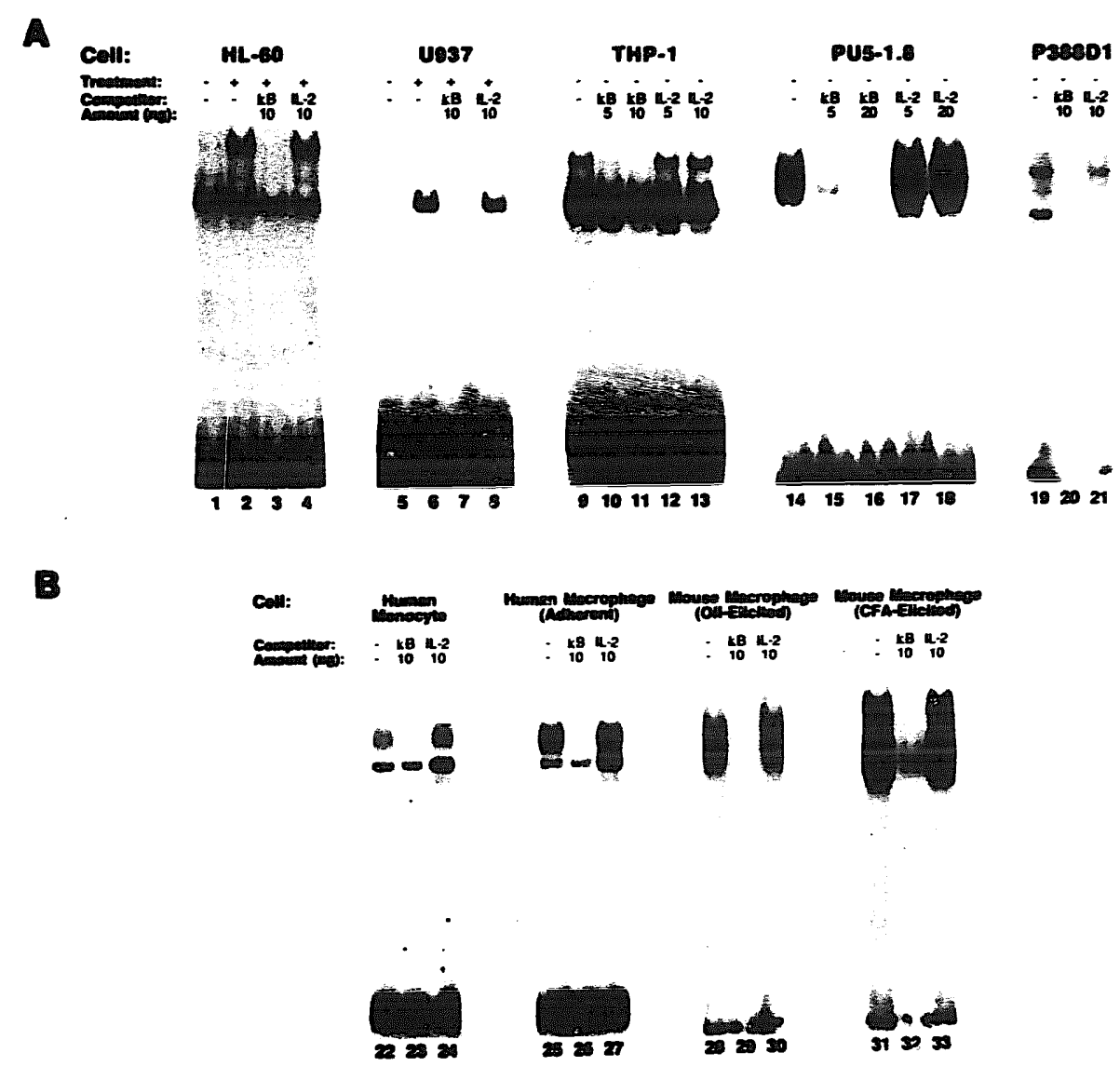

Fig. 1A. NF- $x$ B-binding activity in nuclear extracts of immature monocyte cell lines is induced by exposure to 40 nM TPA (lanes 1-8) and is found constitutively in mature macrophage cell lines (lanes 9-21).

Arrows denote specific inducible complexes completed by double-stranded $x B$ oligonucleotide. Fig. 1B. NF-xB-binding activity is demonstrated in human peripheral blood mono-
cytes (lanes 22-27) and elicited mouse peritoneal macrophages (lanes 28-33). 
tion, it has been shown that THP-1 cells acutely infected with HIV demonstrate phenotypic changes associated with maturation, and released significantly higher levels of TNF $\alpha$ and IL-1 $\beta$ compared to chronically infected cells (Molina et al., 1989).

However, the same group reported that in vitro HIV infection of human peripheral blood monocyte/macrophages d:d not result in cytokine production but that these cells retained the capac- ity to produce cytokines after LPS stimulation (Molina et al., 1990). These findings were supported by a similar study using human monocyte/macrophages infected in vitro (Munis et al., 1990). LPS has been shown to be a potent stimulus of HIV1 expression in monocyte/macrophage cell lines, but not surprisingly LPS has no similar activity towards on lymphocytes (Pomerantz et al., 1990). Some evidence is also accumulating that TNF $\alpha$ released from
A

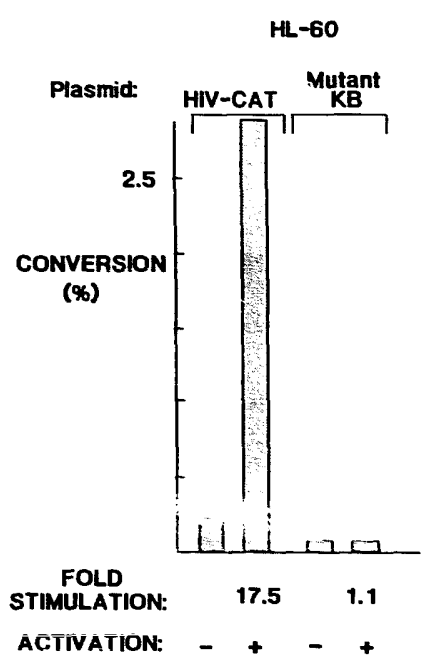

B

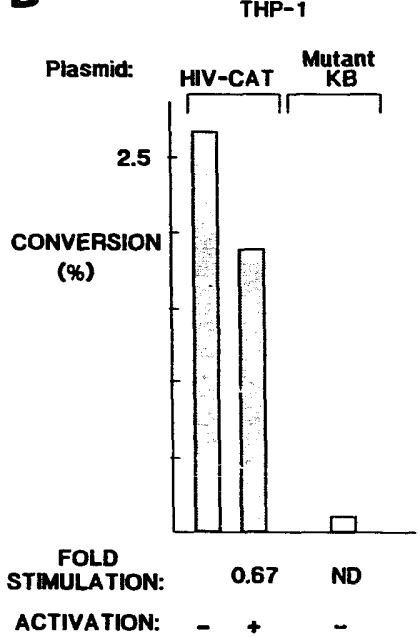

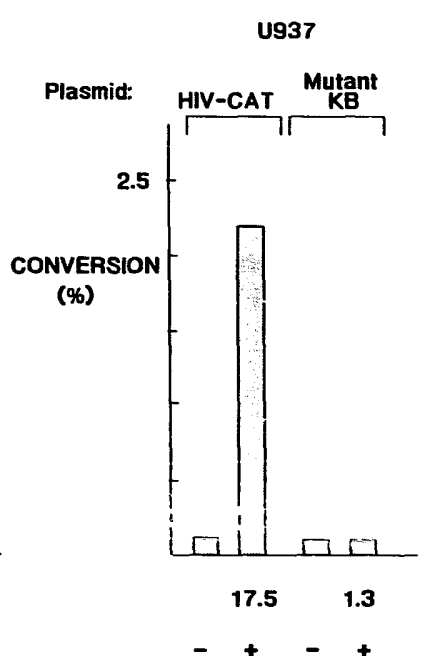

P38801

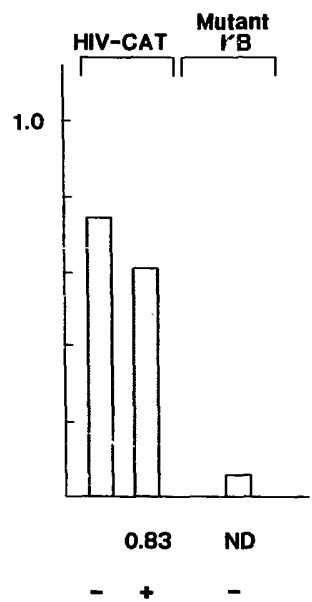

PU5-1.8

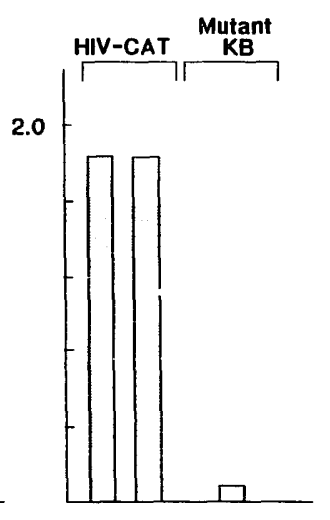

1.0 ND

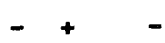

Fig. 2. Activation of HIV-CAT expression in immature monocyte cells (A) is elicited by exposure to $40 \mathrm{nM}$ TPA. In contrast constitutive CAT activity is seen in unstimulated mature cells (B).

monocyte/macrophages may be acting in an autocrine manner in HIV-infected cells to promote HIV activation (Poli et al., 1990).

Macrophages are known to be crucial cells in host defence against infection. Many stimuli are known to activate such cells via different mechanisms and receptors. However, a final common end point of terminal differentiation of monocyte into macrophage appears to be the consitutive expression of NF-r:B. Wo have demonstrated that such differentiation is associated with activation of HIV transcription and virus production in these cells. The relationship of other receptormediated activation processes of macrophages, for example phagocytosis, which are relevant to the in vivo situation clearly deserve investigation.

\section{Acknowledgements}

This work was supported by the Wellcome Trust (G.E. Griffin) and National Institutes of Health (C.Y. Nabel ard S. subikel). ligures are ieprinted by perinission from Nature (Lond.) (1989), 339, 70-73. Copyright (C) 1989, Macmillan Miagazines Limited.

\section{L'induction de NF- $x \mathbf{B}$ au cours de la différenciation des monocytes est associée à l'activation de l'expression des gènes du VIH}

Les cellules de la lignée monocyte-macrophage sont des cibles importantes du VIH (virus de l'immunodéfience humaine). Nous rapportons ici que la différenciation phénotypique de lignées de cellules monocytaires induite par des esters de phorbol ou par le TNF $\alpha$ (tumour necrosis factor) esi associée à l'expression du facteur nucléaire kappa B (NF-xB). Parallèlement à une telle différenciation, la transcription du VIH, contrôlée par la construction d'un gène reportant le LTR (long terminal 

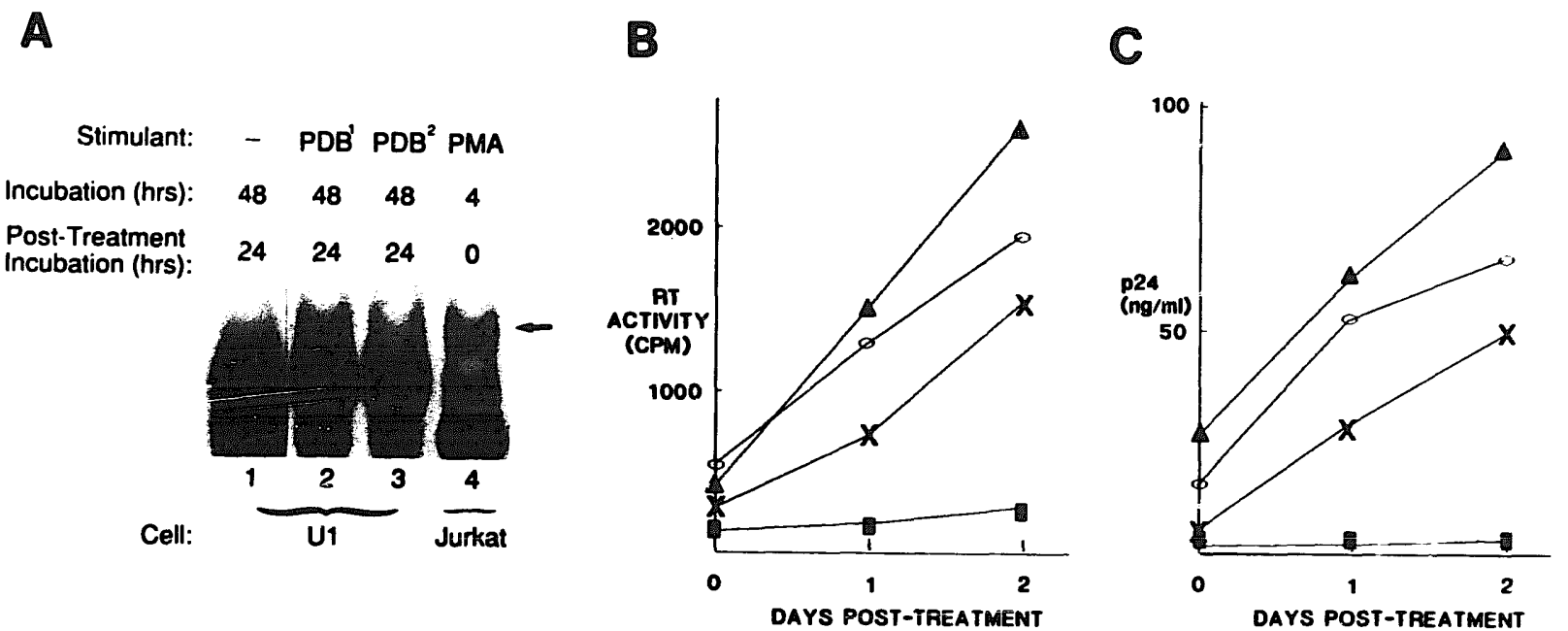

Fig. 3. Increased constitutive expression of NF- $x B$ (A) and HIV (B and C) in an HIV chronically infected promonocytic cell line, U1, following cellular differentiation induced by PDB or TPA.

Reverse transcriptase (RT) activity and p24-antigen activity were determined in tissue culture supernatants (B) as indices of HIV production.

U1 cells were incubated in medium alone $(\boldsymbol{\theta})$ or incubated with $2 \mathrm{nM}$ PDB $(\Delta), 20 \mathrm{nM}$ PDB $(\bullet)$ or $10^{3}$ units/ml TNF $\alpha$ for $48 \mathrm{~h}$ followed by washing and incubation for a further 24 or $48 \mathrm{~h}$.

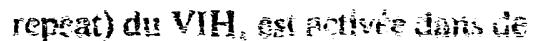
telies celíuies sous i infïuence de l'augmentation de l'expression $\mathrm{NF}=\varkappa \mathrm{B}$. De même, dans une lignée cellulaire promonocytaire infectée chroniquement par le VIH, l'expression du NF-xB et la transcription du VIH sont stimulées par les esters de phorbol ou le TNF $\alpha$. Ainsi, la stimulation de lignées de cellules monocytaires par les esters de phorbol ou par le TNF $\alpha$ induit la différenciatioit cellulairc et active la transcription du VIH. Un tel processus peut avoir des implications fondamentales dans la pathogenèse du VIH in vitro, et peut être important dans la progression de la maladie induite par des infections opportunistes impliquant directement ou indirectement les macrophages.

Mots-clés: VIH, Monocyte, Macrophage, SIDA, Facteur nucléaire kappa $B$; Esters de phorbol, TNF $\alpha$, Maturation cellulaire, Transcription.
Keferesictes

Donahue, R.E., Johnson, M.M., Zon, L.I., Clārk, S.C. \& Groopman, J.E. (1987), Suppression of in vitro haematopoiesis following human immunodeficiency virus infection. Nature (Lond.), 326, 200-203.

Folks, T.M. (1988), Infection and replication of HIV-1 in purified progenitor cells of normal human bone marrow. Science, 242, 919-922.

Folks, T.M., Justerient, J., Kinter, A., Dinarello, C.A. \& Fauci, A.S. (1988), Cytokine-induced expression of HIV-1 in a chronically infected pneumonocyte cell line. Science, 238, 800-802.

Griffin, G.E., Leung, K., Folks, T.M., Kunkel, S. \& Nabel, G.J. (1989), Activation of HIV gene expression during monocyte differentiation by induction of NF- $x$ B. Nature (Lond.), 339, 70-73.

Ho, D.D., Rota, T.R. \& Hirsch, M.S. (1986), Infection of monocyte/ macrophage by human $\mathrm{T}$ lymphotropic virus type III. J. Clin. Invest., 77, 1712-1715.

Koyanagi, Y., O'Brien, W.A., Zhao,
J.Q. Gulde, D. W, Glasson, I.C. \& Chen, I.S.Y. (1988), Cytokines alter production of HIV-1 from primary mononuclear phagocytes. Science, 241, 1673-1675.

Leung Kwanyee \& Nabe!, G.J. (1988), HTLV-1 transactivator induces interleukin-2 receptor expression through an NF-xB-like factor. Nature (Lond.), 333, 776-778.

Meltzer, M.S., Skillman, D.R., Hoover, D.L., Hanson, B.D., Turpin, J.A., Kalter, C. \& Gendelman, H.E. (1990), Macrophages and the human immunodeficiency virus. Immunol. Today, 11, 217-223.

Molina, J.-M., Scadder, D.T., Byrn, R., Dinarello, C.A. \& Groopman, J.E. (1989), Production of tumour necrosis factor $\alpha$ and interleukin $1 \beta$ by monocytic cells infected with human immunodeficiency virus. J. Clin. Invest., 84, 733-737.

Molina, J.-M., Schindler, R., Ferriani, R., Sakaguchi, M., Vannier, E., Dinarello, C.A. \& Groopman, J.E. (1990), Production of cytokines by peripheral blood monocyte/macrophages infected 
with human immunodeficiency virus type 1 (HIV-1). J. infect. Dis., 161, 888-893.

Munis, J.R., Richman, D.D. \& Kornbluth, R.S. (1990), Human immunodeficiency virus-1 infection of macrophages in vitro neither induces tumour necrosis factor (TNF)/cachectin gene expression nor alters TNF/cachectin induction by lipopolysaccharide. J. Clin. Invest., 85, 591-596.

Nabel, G.J. \& Baltimore, D. (1987), An inducible transcription factor activates expression of human immunodeficiency virus in $T$ cells. Nature (Lond.), 326, 711-713.

Osborn, L., Kunkel, S. \& Nabel, G.J. (1989), Tumor necrosis factor $\alpha$ and interleukin 1 stimulate the human immunodeficiency virus enhancer by activation of the nuclear factor $\times B$. Proc. nat. Acad. Sci. (Wash.), 86, 2336-2340.

Poli, G., Kinter, A., Justement, J.S., Kehrl, J.H., Bressler, P., Stanley, S. \& Fauci, A.S. (1990), Tumour necrosis factor $\alpha$ function in an autocrine manner in the induction of human iminunodeficiency virus expression. Proc. nat. Acad. Sci. (Wash.), 87, 782-785.

Pomerantz, R.J., Feinberg, M.B., Trono, D. \& Baltimore, D. (1990), Lipopolysaccharide is a potent monocyte/macrophagespecific stimulator of human immunodeficiency virus type 1 expression. J. exp. Med., 172, 253-261.

Vyakarnam, A., McKeating, J., Meager, A. \& Beverley, P.C. (1990), Tumour necrosis factors $(\alpha$ and $\beta$ ) induced by HIV-1 in peripheral blood mononuclear cells potentiate virus replication. AIDS, 4, 21-27. 